\title{
Child sexual abuse violence against human dignity of children
}

Ngo, Ngoan $\bowtie$

De La Salle University Manila, Philippines (ngoan_ngo@dlsu.edu.ph)

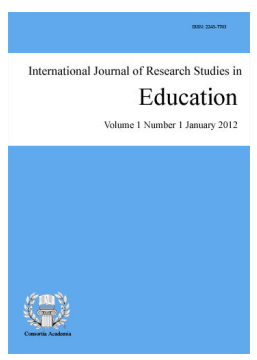

Accepted: 20 October 2021

ISSN: 2243-7703 Online ISSN: 2243-7711

OPEN ACCESS

\section{Abstract}

By using the literature review method, this paper would like to convey the issues of child sexual abuse which violates rights and dignity of children. Children are the lowest level and the most vulnerable in society who need the care and protection from the family, religion, and society. However, many of them are victims of violation and sexual abuse by the family members, educators, religious people and the others. According to Christian morality, child sexual abuse is a sin against the sixth Commandment and the dignity of children. It injuries the respect, freedom, and moral aspects of a person. Additionally, child sexual abuse negatively impacts the mental health, physical health, moral and spiritual development of the abused victims. Giving different perspectives from the Scriptures, the teachings of the Church, and the society, the researcher wants to confirm that children have the same dignity and rights with the adult, hence, any forms of violence towards children are unaccepted. The Church and the society strongly condemn child sexual abuse, and try protect children' dignity and rights. In order to prevent child sexual abuse, this paper would like to give two suggestions: increasing awareness of the rights and dignity of children for all people, and child sexual abuse prevention training. This paper aims to raise the voice to respect dignity of children and protect them from the harms of violence, especially child sexual abuse.

Keywords: children, child sexual abuse, human dignity, rights, protection. 


\section{Child sexual abuse violence against human dignity of children}

\section{Introduction}

Children are the future of a nation and the world who should be provided a safe environment and a healthy education to grow up and fully develop potentiality. However, in recent years, numbers of violence against children have increased. According to World Health Organization (2020), about 1 billion children aged 2-17 years all over the world have experienced physical, sexual, or emotional violence or neglect in 2019. Child sexual abuse (CSA) is a moral panic alarming the moral and ethical decline the modern society (Salter, 2018). CSA impacts the childhood, physical, psychological, and moral development of children (Stogsdill, 2019). Especially CSA is a sin against rights and dignity of children, and the value of Gospel, "Let the little children come to me, and do not hinder them, for the kingdom of God belongs to such as these (Mark 10:14). Pope Francis said to Sunday in Philadelphia after meeting with victims of sexual abuse, "God weeps for sexual abuse of children" (BBC News, 2015). Understanding the serious problems of child sexual abuse as well as raising the voice to fight against it and protecting children, this paper conveys the background of child sexual abuse, the human dignity and rights of children, the perspective of the Church and the society about CSA. Additionally, the researcher would like to give some suggestions for protection of children from CSA.

\section{Methodology}

This paper applied a literature review as the method to explore the impact of child sexual abuse on children's rights and dignity. The data were gathered through review of literature from books, journals and websites containing data relevant to the research. The statistics were collected from different sources to explore the context of CSA. The forms, causes and risks of child sexual abuse were conducted through an analysis from electronic databases such as JSTOR, Taylor\& Francis, ProQuest, ResearchGate and the documents of UNICEF, and WHO. The Scriptures and the magisterial teachings would be used to review human dignity, and human rights. Besides, the social documents such as Declaration on the rights of the child and adhered to the relative Convention, and the United Nations Convention on the rights of the child were applied to protect children from sexual abuse. By using the data from different sources, this paper aims to discover the issues of child sexual abuse today and how the Church and the society respond for this issue to protect the rights and dignity of children.

\section{Discussion}

\subsection{Current context of child sexual abuse}

Child sexual abuse - World Health Organization (2020) defines child sexual abuse, "Child sexual abuse is the involvement of a child in sexual activity that he or she does not fully comprehend, is unable to give informed consent to, or for which the child is not developmentally prepared and cannot give consent, or that violates the laws or social taboos of society". There are two forms of CSA: contact and non-contact behavior (Zhu, Gao et al., 2015). Sexual contact is a penetrative act, and all non-penetrative acts. Nonsexual contact is the sexual acts without physical contact such as exposing oneself to a child or on the contrary (2020). CSA can happen in the family, schools, the churches or any place children gather. By study from of videos and images in the ICSE database, INTERPOL and ECPAT International (2018) report:

"The younger the victim, the more severe the abuse; $84 \%$ of images contained explicit sexual activity; more than $60 \%$ of unidentified victims were prepubescent, including infants and toddlers; $65 \%$ of unidentified victims were girls; Severe abuse images were likely to feature boys; 
$92 \%$ of visible offenders were male".

In Vietnam, child sexual abuse is very serious when the age of victims is very young. Before the victims of sexual abuse are from 13 to 18 years old, but now from 2 to 13 years old (Newvison Advcates \& Solicitors, 2017)). From January 2015 to June 2019, more than 8700 Vietnamese children were abused. Among them, more than 6400 children were CSA. Many female victims were sexually abused by their relatives, fathers, step-father, and grandfathers (Tuoi tre News, 2020). In the Philippines, about 7,000,000 children are sexually abused every year. More than $70 \%$ of CSA are between 10 and 18 years old, $20 \%$ are under 6 years old. Among the victims, $98 \%$ are girls, many of them were forced into prostitution or pornography, the other were sexually abused because of living on the streets (Cameleon association).

During the pandemic, more children get risks of violence, child labor, child marriage and child sexual abuse because they stay at home most of the time. CSA and online child sexual abuse are increasing during lockdown. According to the Department of Justice in the Philippines, from March to May 2020 there were 202,605 cases, compared to the 76,561 cases during the same period in 2019 (Save the children). In India, 92000 child abuse reports to helpline (World Health Organization, 2020). In the US, the hotline- contact reports $67 \%$ of the perpetrator as a family member, and 79\% the victims live with the perpetrator (Kamenetz, 2020). These numbers are alarming about CSA all over the world. However, the actual number of CSA might be higher than the number reported because many cases are still covered up and unreported by the families of victims.

Causes of child sexual abuse - According to Salter (2018), the moral status of the crime and the lack of responses to CSA are the fundamental causes of CSA. In recent years, the state of morality and ethics have alarmingly decayed such as violence, mass shooting, racial hatred, rape, and sexual abuse. Individualism, subjectivism, materialism, and secularism also impact the moral aspects. People give highlight to individual freedom to define morality by their own situations and perspectives. They do not follow the common standards of morality. Consequently, the moral decline influences the conscience of people. Many abusers have a lax conscience. They do not feel guilty when they commit sins against God and people. They sexually abuse children many times until this problem is exposed. Not all abusers have pedophilia disorder which has acted on his sexual urges. Pedophilia disorder can actually molest a child, or he has masturbated, or has viewed child pornography (American psychiatric association, 2013). If people with pedophilia sexually abusing children, they still have to respond to their criminal acts. Furthermore, when the technology advances, the new forms sexual abuse emerges. Many children are victims of online sexual exploitation. The black net or blackmail uses the videos or images of children for sexual purposes. This act is considered child pornography. The victims suffer more when their images or videos are shared and viewed millions of times.

The lack of responses for CSA contributes to the sexual issues seriously. The perpetrators threaten the victims to keep the secret. Additionally, parents, especially parents in rural areas are very busy who do not take care enough for children and do not teach them to prevent CSA. Some parents only recognize their daughters are sexually abused when they get pregnant. Moreover, the perpetrators might be fathers, grandfathers, stepfathers, relatives, even educators and religious people. The families conceal the sexual victimization of a family member because of fearing of losing the name of family and the future of the victim (Zhu et al., 2015; Do et al., 2019). The other cases, the family knows their children were abused very late, so they lack evidence to condemn the abusers. Hence, many abusers are not arrested and punished. The neglecting of responses for CSA from the family and society is unjust for the victims. While the perpetrators are out of the judgment, the victims endure suffering and pain for the rest of their lives. Many of them commit suicide when they are abused but could not tell anyone, or parents do not protect them from the harm of sexual abuse by the family members. Additionally, in many countries, the law on CSA is ambiguous which does not distinguish the forms of sexual abuse and the punishment for this crime. Therefore, the figure of abused victims is increasing every year.

Impact of child sexual abuse on children - Child sexual abuse impacts to both physical, psychological, spiritual and moral development of the abused survivors. Sexual contact abused such as anal, vaginal, or oral 
penetration causes health risks. The victim might get physical illness from the perpetrators such as HIV, and unwanted pregnancy (Mathews \& Collin-Vezine, 2016). Additionally, CSA can significantly impact a brain of the victim as it develops, and negative effects in their adulthood (Tailor et al., 2014; Salter, 2018; Stogsdill, 2019). The victims who directly contact the abusers such as fathers, step-fathers, and grandfathers often tend to be in psychological distress and risk being abused many times (Sanjeevi, Houlihan et al., 2018). They might get mental disorders such as anxiety disorder, depression, posttraumatic stress disorder, sexual disorder, eating disorder, and sleeping (Hall, M., \& Hall, J., 2011; Barrera, et al, 2013; Zhu et al., 2015; Salter, 2018; Stogsdill, 2019). Moreover, CSA affect their emotions and feelings such as rejection, isolation, verbal assault, nightmares, flashbacks, and disorientation (Hall, \& Hall, 2011; Stogsdill, 2019).

Child sexual abuse also impacts to their spiritual and moral development (Stogsdill, 2019). They see their body negatively, dirtily; thus, they feel shame, guilt, and unworthiness. (Hall \& Hall, 2011). They blame themselves and self-harm. Many of them commit suicide or avoid communicating with other people. Male survivors of CSA can get incorrect behaviors as they grow such as drinking alcohol, gambling, using drugs, and criminal actions. They might become sexual abusers in their adulthood. According to a study, children have experience or witness child sexual abuse are 24 times more likely to commit sexual assault crimes, 50 times likely to abuse drugs or alcohol, 74 times more likely to commit a crime against other people compared to those who did not experience CSA (cited in Stogsdill, 2019). Female survivors of CSA might become prostitution when they live in poverty, or their parents force them to sell sexuality at their young age. Additionally, children often learn morality and ethics from the adults, the family, and educators. Witnessing the immoral actions of them, children can be influenced negatively by their behaviors and actions, they may not distinguish what is right and wrong. They can imitate the adults to do wrong deeds. Thus, CSA significantly influences the victims' moral development. For the impact of religiosity or spirituality, the rate of women with CSA histories defects more than women without that history. Many of them left the community faith or changed to another belief. Women with CSA survivors have negative views of God such as God is more distant, judgmental, unloved, and harsh (Tailor et al., 2014).

\subsection{Human dignity of children}

Human right and dignity - The Catechism of the Catholic Church 356 (CCC) explains, "Man alone is called to share, by knowledge and love, in God's own life . . . This is the fundamental reason for his dignity. Being in the image of God, the human individual possesses the dignity of a person, who is not just something, but someone". According to May (2003), the tradition of the Church divides human dignity into three kinds. The first dignity of human beings is the dignity as simply they are human beings who are created in God's own image and likeness (Genesis 1:26-27). Gaudium et Spes (Kroeger, 2011) confirms that all people including children, the elderly, men, and women have the same dignity and equal values. They have equality in respecting their dignity and rights because they are all children of God, the same nature and origin, saved by Christ, and enjoy the same divine calling and destiny. The second kind of dignity is the dignity built in human intellectuality and free choice. They are given this dignity to make the good moral choices upon the true moral judgments and responsibility. They have the right to accept or reject, to do good and to avoid evil. The third kind of dignity is the dignity based on the relationship with God and people. All people are children of God, brothers and sisters of Jesus, members of the divine family. This dignity is a gift from God through God's creation and salvation, especially through the sacrifice of Jesus to save all people and bring them back to the family of God. As children of God and siblings of each other, they are called to respect the dignity of each other. This dignity can be lost when they freely choose evil, to be against God and other people. Thus, dignity is given to all people, whoever they are, they are worthily treated as being moral who cannot be used as an object or the means to an end (May, 2003).

Dignity of children - Children are often considered inferior and have less autonomy to adults in nearly every way. Somehow, they are treated unfairly just because they are children and depend on the adult (Sigurdsen, 2020). The adult often demands children to respect and obey them, but they show disrespect to children, even embarrass and violate them. This treatment is against the rights and dignity of children. According to the 
teachings of the Church and the Universal Declaration of Human Rights, children have the same right and equal dignity as adults. The Church stresses on protecting and respecting human life and human dignity from the moment of conception since a human embryo is a person with dignity and life is sacred from God (Reginald, 2017). The Church urges the families and institutions to have "concern for the child, even before birth, from the first moment of conception and then throughout the years of infancy and youth, is the primary and fundamental test of the relationship of one human being to another." (John Paul II, 1981).

Children are the future of all nations and the world, so the family, society and the nations need to respect their rights and dignity, as well as providing suitable conditions for their growing up and developing their potential. The family is the first place to protect the rights and dignity of the children: "In the family, which is a community of persons, special attention must be devoted to the children by developing a profound esteem for their personal dignity, and a great respect and generous concern for their rights" (John Paul, 1981, no.26).

Besides, human institutions have to promote the dignity of children. The Church has recognized the Universal Declaration of Human Rights as "a true milestone on the path of moral progress of humanity" (cited in Francis, 2017). The Declaration (United Nations, 2015) affirms "All human beings are born free and equal in dignity and rights. They are endowed with reason and conscience and should act towards one another in a spirit of brotherhood" (\#1). Thus, all children are cared, protected and "given opportunities and facilities to develop physical, mental, moral, spiritually and socially in a healthy and moral manner and in conditions of freedom and dignity (\#2). Furthermore, the acritical 6 of the Convention explains all the rights, and the responsibilities of governments for children. "Every child has the right to be alive. Governments must make sure that children survive and develop in the best possible way" (Unicef, 1989).

\subsection{Child sexual abuse violates human dignity of children from different perspectives}

Biblical perspective - The Scripture does not directly mention about child sexual abuse but speaks strongly against the molestation of children. There are some stories in the Scripture that children are violated and killed (See. Exodus 1:15-22; Matthew 2:16-18), neglected, not counted (See. Matthew 14, 21), and rebuked (See. Matthew 19:13). In the patriarchal society, children belong to the lowest class, the inferior, and the vulnerable. They have no right to speak out, to defend themselves, and have to depend and obey the parents. They are treated unfairly by the adults. However, God listens to their suffering and crying. God condemns those oppressing children, "So I will come to put you on trial. I will be quick to testify against sorcerers, adulterers and perjurers, against those who defraud laborers of their wages, who oppress the widows and the fatherless, and deprive the foreigners among you of justice, but do not fear me" (Malaki 3:5). Those who do injustice to other people will be punished, "Woe to those who make unjust laws, to those who issue oppressive decrees, to deprive the poor of their rights and withhold justice from the oppressed of my people, making widows their prey and robbing the fatherless" (Isaiah10: 1-2). Those who commit sexual immorality cannot inherit the kingdom of God (See. Galatians 5:19-21; 1 Corinthians 6:9). Sexual assaulting children is immoral act which is always condemned, "But as for the cowardly, the faithless, the detestable, as for murderers, the sexually immoral, sorcerers, idolaters, and all liars, their portion will be in the lake that burns with fire and sulphur, which is the second death" (Revelation 21:8).

In the New Testament, Jesus shows special affection for children as the way to protect and respect their dignity. He becomes one with children by sharing human nature, and difficulties during his childhood. He was a victim of violence when he was young. Herod wanted to kill Him, so His family had to bring him to flee to Egypt, then return from Egypt to Nazareth (See. Matthew 2:13-23). Hence, He understands the difficulties and challenges of the violated victims. He welcomes and blesses them (See. Mark 10:16). He healed many children from disease (See. John 4:46-52), casting out demons (See. Mark 7:24; 9:14-27), and raising a child from the dead (See. Luke 8:40-56). He places children as modelling of the Kingdom of heaven (See. Matthew 19:14), and rebukes those who gives scandal to children, "It were better for them to have a great millstone fastened around their neck and to be drowned in the depth of the sea" (Matthew 18:6). Jesus saves children from all harms and 
Ngo, N.

dangers because children are precious gifts from God. They have the right to be provided a good conditional life to enrich their development with a sense of justice and respect their dignity as well as the dignity of other people. In Colossians 3: 21, Saint Paul encourages the parents, "do not provoke your children, lest they become discouraged".

The Church's perspective - In Gaudium et Spes, the Church declares whatever is opposed to life itself, such as murder, genocide, abortion, and euthanasia, violation, whatever insults human dignity, such as subhuman living conditions, arbitrary imprisonment, deportation, slavery, prostitution, the selling of women and children, disgraceful working conditions are infamies and dishornor to God. CSA is a sin against the Sixth commandment and violates dignity of children because CSA is considered as raping children. According to CCC 2356, "Rape is the forcible violation of the sexual intimacy of another person. It does injury to justice and charity. Rape deeply wounds the respect, freedom, and physical and moral integrity to which every person has a right. It causes grave damage that can mark the victim for life. It is always an intrinsically evil act. Graver still is the rape of children committed by parents (incest) or those responsible for the education of the children entrusted to them". Rape is a grave sin because it is sexual act outside of marriage (CCC 2390), and force the victim to have sex, as well as it damages the life of the victims. Moreover, child sexual abuse is a great intrinsically evil act. Children are minors who do not fully grow up in both physical, psychological and emotional aspects. They are simple, innocent and unable to take care, and protect themselves from the violation and abuse of the adult, especially when the abusers are family members, educators, the clergy and religious people. Additionally, by "the forcible violation of the sexual intimacy of another person", the abusers are against the right and freedom of children; at the same time, they express the dominion over children to force them for sexual intimacy. Children have no choice to avoid the evil act of the abusers. According to Gaudium et Spes, number 17, "Man's dignity demands that he acts according to a knowing and free choice that is personally motivated and prompted from within, not under blind internal impulse or by mere external pressure" (Kroeger, 2011). Freedom of children is controlled by the power of the abusers. There is external pressure to do sexuality, so their dignity is damaged. CSA is also against the right of safety, protection and caring of children. Therefore, the family needs to give special attention to the development, personal dignity, and rights of children, especially the small children, the handicap, and the sick (John Paull II, 1981).

Nowadays, the social environment is rapidly changing with many new trends which threaten the dignity and the healthy environment for the development of children. Moreover, the global crisis at once environmental, social, economic, political, moral and spiritual significant impact to the life of children. Particularly, the digital world which can bring a lot of benefits for people in terms of communication, business, information, learning, and entertainment becomes a risky world when people abuse, or use it for bad intentions. Pope Francis (2017) raises the problems of the digital world which influence children's development. He reports that over 800 million minors access the internet. In India, half of over 500 million people have access to the internet. The troubling things on the internet consist of online child sexual abuse in forms of pornography, sexual live streaming, only harassment, online trafficking, consuming child sexual abuse material, coercing and black mail for sexual purpose. Child sexual abuse images online becomes popular on the internet when million pictures of children used to sexual purpose. Millions of views and sharing of sexual images or "black videos" are sources of harm to the psychology and health of the victims. Thus, child sexual abuse image online is social problem which violate children rights (Martin \& Slane, 2015). Pope Francis also affirms these issues are a true form of moral and physical attack on dignity of young people, and "sexual abuse is a grave error and the source of many other evils" (2017).

Social perspective - Living in the modern world, but children, especially children in the poor countries still undergo hard trials, child labor, maltreatment, child marriage, exploitation, violence, and inhuman values. Among these problems, child sexual abuse is serious issue negatively affecting millions of children all over the world. CSA impacts public health, social justice, human rights, human dignity, gender equality, science and ethics (Mathew \& Collin-Vezina, 2016). Children are often treated injustice, less respect of dignity, and missing voice. In the family, parents require children to respect and obey the adult, but they do not respect the rights and

102 Consortia Academia Publishing (A partner of Network of Professional Researchers and Educators) 
dignity of children. In some cultures, children can only speak when the parents permit them, or parents control all activities of children, even parents abuse and violate children (Noghabi et al., 2019). Additionally, gender discrimination is a risk factor for CSA (Sanjeevi, Houlihan et al., 2018). The numbers of girl are sexually abused more than boys (Zhu et al., 2015; Gray \& Rarick, 2018; Sanjeevi, Houlihan et al., 2018). Girls are two or three times more likely to be sexually abused compared to boys (Gray \& Rarick, 2018).

In some cultures, children, particularly the girls, are forced to get married at a young age. The parents do not support the education for children, but arrange a marriage with another child or an adult without giving consent. According to UNICEF, there are ten million additional girls at risk of child marriage due to covid-19 pandemic. UNICEF Executive Director Henrietta Fore said, "Covid-19 has made an already difficult situation for millions of girls even worse. Shuttered schools, isolation from friends and support networks, and rising poverty have added fuel to a fire the world was already struggling to put out. But we can and we must extinguish child marriage" (2021). UNICEF confirms that child marriage is the result of entrenched gender inequality and it is a fundamental violence of human rights. Child marriage is considered as a form of child sexual abuse and exploitation of girls (Rembe et al., 2011). Child forced marriage is against the article 16 of the Universal Declaration of Human Rights, “(1) Men and women of full age, without any limitation due to race, nationality or religion, have the right to marry and to found a family. They are entitled to equal rights as to marriage, during marriage and at its dissolution. (2) Marriage shall be entered into only with the free and full consent of the intending spouses". Children who are not "full of age" still need the care and protection from the adult, but when they get married, they become the household, taking charge of all the tasks of the family. They may get risks of marriage including social isolation, no education, responsible for household chores, domestic violence, sexual force, poverty, and teen mother.

Sexual violence in increasing yearly all over the world, especially during the pandemic when children spend much time within the family. Most children facing sexual abuse undergo other kinds of violence such as torturing, exploitation. Cappa and Petrowski (2020) review all forms of violence against children on the occasion of thirty years of the adoption after the Convention on the Rights of the Child (Unicef, 1989). They point out the statistical evidence documents of the old and new forms of violence, from harsh disciplinary methods to online bullying including corporal punishment, psychological aggression, sexual abuse and intimate partner violence. Some forms of child abuse such as commercial sexual exploitation, sexual against boys, and psychological maltreatment are often ignored or not reported exactly number, so the number of violence are only a part of the real huge number of victims. This statistic can impact the increasing CSA when people do not properly recognize the risks of CSA. This study discloses social status and economics such as gender, race, and social class connected to child violence. Children in the poor areas are often abused, oppressed, and have lesser educational opportunities than children in the urban areas. Moreover, the lack of knowledge of children's rights and the dignity of adults can contribute to children's violence.

Recognize the serious consequences of child sexual abuse and maltreatment, the society gets more concern for the rights and dignity of children. The laws of rights and human dignity of children are discussed to defend children from the harms of violence. The universal laws signed by the presidents of many countries such as the Universal Declaration of Human Rights, the Declaration on the Rights of the Child, the United Nations Convention on the Rights of the Child are the human laws to nurture the human dignity of children and to prevent violations of children's dignity and rights (Polonko \& Lombardo). Article 19 of the United Nations Convention on the Rights of the Child declare "Governments must protect children from violence, abuse and being neglected by anyone who looks after them" (United Nations, 2015). On November 4, 1950 the Council of Europe adopted the European Convention for the Protection of Human Rights and Fundamental Freedoms to affirm the fundamental rights and freedoms of all human beings, and to fight against any form of discrimination. In the cases of children as victims of CSA and other violence, their rights are examined in Article 2 (Right to life), Article 3 (Prohibition of inhuman or degrading treatment), Article 8 (Right to respect for private and family life), Article 13 (Right to an effective remedy), and Article 14 (Non-discrimination) of the European Convention (Marino \& et al., 2021). By approving the laws against injustice and violence, the Sate ensures that every child 
Ngo, N.

shall not be subjected to oppression, sexual abuse, violence. When children are abused and violated, they have the right to report these issues, "Children have the right to give their opinions freely on issues that affect them. Adults should listen and take children seriously (United Nations, 2015, \#12). However, the sexual abused victims are threatened to report the evil issues to the authorities or the family. The other victims feel shame and guilt for telling other people. The silence of the victims and the families can cause CSA more seriously, and give a chance to the abusers to escape from investigation. People need to be aware that "childhood sexual abuse infringes on the basic rights of human beings" (Hall \& Hall, 2011). Any one violating children through CSA and other maltreatment is unacceptable.

\section{The prevention of childhood sexual abuse}

Child sexual abuse is a serious issue impacting the entire life of the victims who are the most vulnerable in the society. CSA causes the death, physical illness, and psychological disorder and moral issues, the human dignity and rights of children. Prevention and protection of children from CSA are the responsibility of all people, the family, society, school and religion. The Church needs to collaborate with the secular world to prevent violence done to the minor and disability. In recent years, the Church has strongly confronted the scandal of CSA in the Church. Pope John Paull II called CSA "an appalling sin in the eyes of God". Pope Francis admits the scandal of CSA in the Church is "an absolute, monstrosity, a horrible sin, radically against everything that Christ has taught us" (Waterloo Catholic). In this part of the paper, the researcher would like to give some suggestions to prevent children from the harm of CSA.

\subsection{Raising awareness of rights and human dignity of children}

Children are human beings having the same dignity and rights as adults. Adults need to acknowledge children's rights and dignity with affection and respect. However, the family often considers children as minor, inferior, depending on the adult, so they ignore their dignity, dominate over them, and control their childhood. Thus, the family needs to be aware of respecting the rights and dignity of their children. Children are the precious gift of God to the family and the fruits of love of their marriage. The parents have the obligation to rear, provide a good environment, and healthy education to develop both physical, psychological and spiritual aspects of children. By taking good care of children, paying attention to them, and learning the skills to recognize the problems of children, especially CSA which children feel difficult to speak out. When children are violated or sexually abused, the parents need to report this evil to the authorities or the helpline. Keeping silence or concealing the issues means to agree with the evil act of the crimes, and treat injustice to the victims. They will be more at risk if the abusers are the family members, and the rest of the family members are threatened or feel ashamed to report CSA to the police. In Vietnam, many girls are abused by grandfathers, fathers, and step-fathers. When they tell their mothers about CSA, but the mothers do not believe, even ignore, blame or punish them. Thus, they are sexually abused for a long time until someone helps them to report to the police.

At the society level, CSA are increasing yearly because the rights and dignity of children are not recognized, the punishment of sexual crimes is not serious, gender discrimination is still dominated, corruption and bribe, the tradition and culture allow child marriage, and the leaders in social institutions lack the will to act, or just ignore the problem to keep the name of institution and personal name (Mathews \& Collin-Vezine, 2016). Therefore, enhanced public awareness of the rights and dignity of children, the serious consequences of CSA, and the responsibility of all people to protect children and fight against CSA and violence children should be of urgency and priority. The government can use social media, or communication, education to provide the knowledge of the laws, children's right and dignity, and to wake up the conscience of people to prevent CSA. Additionally, people need to be aware of social issues relating to CSA and violation such as injustice, gender discrimination, and inequality. In the modern world, men and women are equal, no one can see the other as object of sexuality, but respect each other's gender as their personal identity. Besides, the government and non-governmental organizations can help and support children to increase knowledge of human dignity and rights. Besides, each country has a hotline or helpline to help the victims to report CSA. Furthermore, the organizations provide the 
program to give treatment to the abused survivors. They are hurt in both mental, physical health and emotion. They need the help from the families and the social organizations to heal and recover.

The Church needs to raise the voice to make awareness of children's dignity and rights to people and the society through the teachings of the Church and pastoral ministry. In the Compendium of the social Doctrine of the Church (2004), and Familiaris Consortio (1981), Pope John Paull II pointed out the role of family in caring and protecting the rights and dignity of children. Pope Francis calls for apostolate of prevention to protect children. He gives Guidelines for the protection of children and vulnerable (2019), and Vademecum (2020) on certain points of procedure in treating cases of sexual abuse of minors committed by clerics to confront the scandal of CSA in the Church. These guidelines "are aimed at establishing and maintaining an ecclesial community that is respectful and mindful of the rights and the needs of minors and vulnerable persons, as well as at being vigilant to the risks of exploitation, sexual abuse and ill-treatment in the context of the activities carried out within the sphere of the Vicariate of Vatican City" (Pope Francis, 2020). The Church now does not keep silent or conceal CSA in the Church which has happened for a long time. In order to do justice, the abusers need to take responsibility for their evil acts and be investigated by the state law, the Church's law and the law of their conscience. The pastoral care for the abused survivors is established to take care and assist for the survivors by welcoming them, listening to them and supporting them. The pastoral care can provide them the therapeutic and psychological assistance, health care, spiritual accompaniment to decrease their suffering.

\subsection{Child sexual abuse prevention training}

Children need to be educated and trained on how to prevent CSA from being young. CSA prevention training can be provided by the family, the Church, the school and social organizations. First of all, the family teaches children to know their rights, dignity to respect their personal dignity and others dignity.

"Children must be enriched not only with a sense of true justice, which alone leads to respect for the personal dignity of each individual, but also and more powerfully by a sense of true love, understood as sincere solicitude and disinterested service with regard to others, especially the poorest and those in most need" (John Paull II, 1981).

Family is the first school, parents are the first teachers teaching children the lessons of love, sharing, and respecting each other. Children will observe and learn from the good example of their parents. Hence, if the parents show their love and respect the dignity of children, they will act the same. In the school, the teachers teach children the values and morality, which is right to do and which is wrong to avoid. By understanding dignity and rights, they recognize the value of the body, rights, freedom and responsibility.

Sexual education for children and adolescents is necessary to help them understand and make consciousness of respect for the body, healthy relationships, sexuality, emotional and physical health. Children learn skills to protect themselves from the dangerous situations, to react to an abuser's actions, and to call for help. Sexual education can be taken at home, religious organizations, educational center, and media. Sexual education should lead children to get knowledge and respect the values and moral norms of sexual humanity, avoiding curiosity about sexuality. When children are 3 to 5 years old, the parents can teach them the sexual organs, the private places, the differences between male and female. They explain to children that the other people should not touch their private place o as well as they should not touch the others. They guide children to say "no" or resist the abusers to uncomfortable or unsafe touching. Additionally, the parents encourage children to tell or report when they are sexually abused. In the case children are too young who do not know that they are sexually abused, the parents need to observe the physicality and emotion of children such as their vaginal or anal, penial part are injured, or their sadness, depression, silence, and fear. The adolescence should be guided the healthy sexuality including the capacity to identify the significant relationship with other people, value of body and personal heath, interact with both sexes in respectful and suitable ways, express affection, love, and intimacy properly (Breuner \& Mattson, 2016). The parents need to accompany the adolescence, listen to them and guide them to protect 
Ngo, N.

themselves from the harmful relationships, and give them skills to prevent sexual abuse. Besides, the parents need to guide them to use the digital technologies properly. Plenty of sexual images, videos, and games can attract the curiosity of children. Therefore, parents and adults assist them to avoid the black net, black mail, violation and sexual games.

\section{Conclusion}

Child sexual abuse is an evil act which seriously impact the life of children. The Church and States need to protect children from the violence of children's dignity and rights. Each child has the right to be born, reared, educated and protected, no one has the right to violate and abuse children. Pope Francis has special concern for victims of minor victims of CSA. In the video message to participants in a course held in Mexico on the protection of children, he encourages them to protect the vulnerable numbers, and calls for "Apostolate of prevention" to prevent children from being abused (Watkins, 2019). Providing a healthy environment, a good education, and listening to children with respect for their dignity and rights are the significant elements that prevent CSA. Protection of children is an obligation and conscience of every person because children are now and the future of the family, the Church and a nation. Hopefully, all children grow up in the love, care and protection of family, society, and religion so that their childhood will be happy, joyful and peaceful.

\section{References}

American psychiatric association. (2013). Desk reference to the diagnostic criteria from DSM5.Washington, DC: American Psychiatric Publishing.

Barrera, M., Calderón, L., \& Bell, V. (2013). The cognitive impact of sexual abuse and PTSD in children: A neuropsychological study. Journal of Child Sexual Abuse, 22(6), 625-638. https://doi.org/10.1080/10538712.2013.811141

BBC News. (2015, September 27). Pope Francis on sexual abuse: 'God weeps'. Retrieved from https://www.childhelp.org/pope-francis-on-sexual-abuse-god-weeps/

Cameleon association. Context in the Philippines Child sexual abuse. Retrieved from https://www.cameleon-association.org/contexte-aux-philippines/?lang=en

Catechism of the Catholic Church. Retrieved from https://www.vatican.va/archive/ENG0015/_INDEX.HTM

Claudia Cappa, C., \& Petrowski, N. (2020). Thirty years after the adoption of the Convention on the rights of the child: Progress and challenges in building statistical evidence on violence against children. Child Abuse \& Neglect, 110(1), 104460. https://doi.org/10.1016/j.chiabu.2020.104460

Cora C., Breuner, C. C., \& Mattson, G. (2016). Committee on adolescence and committee on psychosocial aspects of child and family health. Pediatrics, 138(2), e20161348. https://doi.org/10.1542/peds.2016-1348

Do, H. N., Nguyen, H. Q. T., Nguyen, L. T. T., Nguyen, H. D., \& et al. (2019). Perception and attitude about child sexual abuse among Vietnamese school-age children. International Journal of Environmental Research and Public Health, 16, 3973.

Hall, M., \& Hall, J. (2011). The long-term effects of childhood sexual abuse: Counseling implications. Retrieved from http://counselingoutfitters.com/vistas/vistas11/Article_19.pdf

Waterloo Catholic. Information about sexual abuse in the Catholic Church. Retrieved from https://waterloocatholics.org/information-about-sexual-abuse

INTERPOL and ECPAT International. (2018). Towards a global indicator on unidentified victims in child sexual exploitation material. Retrieved from https://www.ecpat.org/wp-content/uploads/2018/03/towards-a-global-indicator-on-unidentified-victimsin-child-sexual-exploitation-material-Summary-Report.pdf

John Paul II. (2004). Compendium of the social doctrine of the Church. Retrieved from https://www.vatican.va/roman_curia/pontifical_councils/justpeace/documents/rc_pc_justpeace_doc_20 060526_compendio-dott-soc_en.html 
Attitude of engineering students towards engineering drawing: A case study

John Paull II. (1981). Familiaris Consortion. Retrieved from https://www.vatican.va/content/john-paul-ii/en/apost_exhortations/documents/hf_jp-ii_exh_19811122_f amiliaris-consortio.html

Kamenetz, A. (2020). Child sexual abuse reports are on the rise amid lockdown orders. Retrieved from https://www.npr.org/sections/coronavirus-live-updates/2020/04/28/847251985/child-sexual-abuse-repor ts-are-on-the-rise-amid-lockdown-orders

Kroeger, J. H. (Ed). (2011). Documents of Vatican Council II. Pasay City: Paulines.

Marino, D.C., Paduano, M. M., Peroni, M. R., \& Sold, M. J. (2021). Violence against young women: A human rights violation. New York: Paul Hastings LLP.

Martin, J., \& Slane, A. (2015). Child Sexual Abuse Images Online: Confronting the Problem. Child \& Youth Services, 36(4), 261-266. https://doi.org/10.1080/0145935X.2015.1092828

Mathew, B., \& Collin-Vezina, D. (2016). Child sexual abuse: Raising awareness and empathy is essential to promote new public health. Journal of Public Health Policy, 37, 304-314. https://www.jstor.org/stable/43948862

Mathews, B., \& Collin-Vezine, D. (2016). Raising awareness and empathy is essential to promote new public health responses. Journal of Public Health Policy, 37(3), 304-314. https://www.jstor.org/stable/43948862

May, W. E. (2003). An introduction to moral theology. Huntington: Our Sunday Visitor Publishing Division. Newvison Advcates \& Solicitors. (2017). Phan tich nguyen nhan xam pham tinh duc o tre em va hinh phat [An analysis of the causes of child sexual abuse and punishment]. Retrieved from https://newvisionlaw.com.vn/phan-tich-nguyen-nhan-xam-pham-tinh-duc-o-tre-em-va-hinh-phat.html

Noghabi, F. A., Yektatalab, S., Momennasab, M., Ebadi A., \& Zare, N. (2019). Exploring children's dignity: A qualitative approach. Electron J Gen Med, 16(2), 2516-3507. https://doi.org/10.29333/ejgm/94093

Polonko, K. A., \& Lombardo, L. X. (2005). Human dignity and children: Operationalizing a human rights concept. Global Bioethics, 18(1), 17-35. https://doi.org/10.1080/11287462.2005.10800863

Pope Francis. (2019). Guidelines for the protection of children and vulnerable persons. Retrieved from https://www.vatican.va/resources/resources_protezioneminori-lineeguida_20190326_en.html

Pope Francis. (2020). Vademecum. Retrieved from https://www.vatican.va/roman_curia/congregations/cfaith/documents/rc_con_cfaith_doc_20200716_va demecum-casi-abuso_en.html

Reginald, A. (2017). The Catholic Church's perspective of human dignity as the basis of dialogue with the secular world. Stellenbosch Theological Journal, 2413-9467. http://dx.doi.org/10.17570/stj.2017.v3n2.a10

Rembe, S., Chabaya, O., Wadesango, N., \& Muhuro, P. (2011). Child and forced marriage as violation of women's rights, and responses by member states in Southern African development community. Agenda, 25(1), 65-74. https://doi.org/10.1080/10130950.2011.575586

Sanjeevi, J., Houlihan, D., Bergstrom, K. A., Langley, M. M., \& Judkin, J. (2018). A review of child sexual abuse: Impact, risk, and resilience in the context of culture. Journal of Child Sexual Abuse, 27(6), 622-641. https://doi.org/10.1080/10538712.2018.1486934

Save the children. (2020). Online sexual abuse of children rising amid Covid-19 pandemic. Retrieved from https://www.savethechildren.org.ph/our-work/our-stories/story/online-sexual-abuse-of-children-rising-a mid-covid-19-pandemic/

Sigurdsen, R. (2020). Children's right to respect for their human dignity. In Children's Constitutional Rights in The Nordic Countries (pp. 19-36). https://doi.org/10.1163/9789004382817_003

Stogsdill, S. (2019). The impact of childhood abuse on moral development. Orphans and Vulnerable Children Student Scholarship. https://pillars.taylor.edu/ovc-student/1

Tailor, K., Piotrowshi, C., Woodgate, R. L., \& Letourneau, N. (2014). Child sexual abuse and adult religious life: Challenges of theory and method. Journal of Child Sexual Abuse, 23(8), 865-884. https://doi.org/10.1080/10538712.2014.960633

Tuoi tre News. (2020, May 30). Over 8,700 kids in Vietnam abused in 4.5 years: NA report. Retrieved from 
Ngo, N.

https://tuoitrenews.vn/news/society/20200530/over-8700-kids-in-vietnam-abused-in-45-years-na-report/ $\underline{54836}$

UNICEF Vietnam for every child. Child sexual abuse recommended reforms. Retrieved from https://www.unicef.org/vietnam/media/3396/file/Child\%20Sexual\%20Abuse\%20recommended\%20refo rms.pdf

UNICEF. (1989). The convention on the rights of the child. Retrieved from https://www.unicef.org/media/60981/file/convention-rights-child-text-child-friendly-version.pdf

United Nations. (2015). Universal declaration of human rights. Retrieved from https://www.ohchr.org/en/udhr/documents/udhr_translations/eng.pdf

Watkins, D. (2019). Pope: 'Apostolate of prevention' needed to protect minors from sexual abuse. Retrieved from https://www.vaticannews.va/en/pope/news/2019-07/pope-francis-video-message-protection-minors-cou rse-mexico.html

World Health Organization. (2020). Addressing violence against children, women and older people during the covid-19 pandemic: Key actions. Retrieved from https://www-jstor-org.dlsu.idm.oclc.org/stable/pdf/resrep28197

World Health Organization. (2020, June 8). Violence against children. Retrieved from https://www.who.int/news-room/fact-sheets/detail/violence-against-children

Wylie, H. (2021). 10 million additional girls at risk of child marriage due to Covid-19 - UNICEF. Retrieved from https://www.unicef.org/eap/press-releases/10-million-additional-girls-risk-child-marriage-due-covid-19unicef

Zhu, Q., Gao, E., Cheng, Y., Chuang, Y., Zabin, L., Emerson, M. R., \& Lou, C. (2015). Child sexual abuse and its relationship with health risk behaviors among adolescents and young adults in Taipei. Asia-Pacific Journal of Public Health, 27(6), 643. https://www.jstor.org/stable/26725669 